\title{
Comparative Studies on the Tongue of White-throated Kingfisher (Halcyon smyrnensis) and Common buzzard (Buteo buteo)
}

\author{
Abd El-Fattah B. M. El-Beltagy \\ Zoology Dept., Faculty of Science, Damanhour University, Egypt \\ Beltagyaaa@yahoo.com
}

\begin{abstract}
The aim of the current study was to investigate and evaluate the ultrastructural and histological aspects of the tongue as well as the histochemical features of the lingual salivary glands of the white-throated kingfisher (Halcyon. smyrnensis); a piscivorous bird and common buzzard (B.buteo); an omnivorous bird. The tongues of the two selected species were investigated in an attempt to elucidate whether variations in the nature of diet may associate with special adaptive lingual structures. Six animals of each studied species were used for the present work. The observed results elucidated that, the tongue of white-throated kingfisher was triangular and occupied $1 / 2$ length of the beak while, the tongue of common buzzard was elongated and biforked at its apex and occupied 2/3 length of the beak. The tongue of common buzzard was longer than that of $H$. smyrnensis. Morphologically, three parts were distinguished in the dorsal surface of the tongue for the two studied species: the apex, the body and the root. The results showed numerous fine hard processes on dorsal surface of H.smyrnensis tongue. On the other side, such processes were apparently absent in the tongue of common buzzard. The dorsal surface of common buzzard tongue was keratinized. In contrast, such keratinization was absent in the tongue of white-throated kingfisher. The recorded results manifested that the salivary glands of both species were mostly simply branched tubular that open on the surface of epithelium by glandular orifices. The glands were well developed and widely distributed in the lingual mucosa of the common buzzard in compared with those of white-throated kingfisher. However, the latter species showed a unique feature that represented by existence of numerous simple tubular mucus glands arranged as one raw on the dorsal lingual epithelium. In addition, the present findings indicated that, the lamina propria of H.smyrnensis tongue had connective tissue and filiform papillae. In particular, the dorsal surface at junction between the lingual body and root of H.smyrnensis was covered by pseudostratified ciliated columnar epithelium.

The histochemical investigations revealed that, the salivary glands were made of mucoserous cells that elaborate neutral mucosubstances, acid mucosubstances and proteins, in which the glands of $H$. smyrnensis showed stronger reaction for neutral and acid mucosubstaces and weaker reaction for protein comparing to those of common buzzard.
\end{abstract}

Key words: Tongue, Birds, Scanning, Histology, Hitochemistry, Salivary glands

\section{INTRODUCTION}

Birds are highly spread out through the whole global inhabiting all the different habitats; the air, land, and around fresh and sea water. Although the highly diversity of the birds, keratinization of the lingual epithelium is a common feature (Iwasaki, 1992 ; Iwasaki et al., 1997 ; Kobayashi et al., 1998), in particular on the ventral side of the tongue, where the so-called 'lingual nail' is prominent in all species examined (Susi, 1969; Homberger \& Brush, 1986 and Carver\& Sawyer, 1989). In the ancestors of birds, the lingual epithelium might become adapted to dry conditions. In birds, the lingual papillae also play an important role in feeding, in which the birds eat hard foods have structures similar to teeth in their upper and lower beaks. Additionally, hard processes at the edge of both sides of the tongue are located next to the inside of 
the beak (Iwasaki et al., 1997). These structures act co-operatively during feeding and mastication. The dorsal surface of the lingual epithelium of Sterna albifrons is covered by numerous fine processes, which keep food on the tongue's surface (Iwasaki, 1992). The same structures are useful for holding food, such as fish, within the mouth (Kobayashi et al., 1998). The taste buds of birds are distributed not only in the lingual epithelium but also in the epithelium of other parts of the oral cavity, as seen also in reptiles (Kutuzov \& Sicher, 1951; Gentle, 1971; Ganchrow \& Ganchrow, 1985). In some cases, taste buds have been found in the deep area of the lingual epithelium of the dorsal radix, and long ducts connect the buds to the dorsal surface of the tongue. The openings of these ducts at the dorsal surface are called taste pores (Ganchrow \& Ganchrow, 1985).

The microstructure of the tongue has been examined in many species of birds, e.g., in parrot, penguin, little tern, owl, white-tailed eagle, hen, quail, and bean goose (Homberger \& Brush, 1986; Iwasaki \& Kobayashi, 1986; Homberger \& Meyers, 1989; Iwasaki, 1992; Iwasaki et al., 1997; Kobayashi et al., 1998; Jackowiak \&Godynicki, 2005; Rossi et al., 2005; Jackowiak et al., 2006; Emura \& Chen, 2008).

Little attention have been paid to the lingual salivary glands of the nonmammalian vertebrates, especially birds (Fujii \&Tamura, 1966; Jerrett \& Goodge, 1973; Taib \& Jarrar,1998, 2001) while investigations on vertebrates lingual salivary glands were mainly concentrated on mammals. Morphological studies showed that salivary glands are absent in some birds such as the pelicanns but are present in others. They are poorly developed in birds that eat soft diet such as piscevorous species and well developed in granivorous, insectivorous and woodpeckers species (King \& McLelland, 1984; Blanks, 1993). Saliva in birds is primarily a lubricant or a sticky coat to the tongue to glue food and ease swallowing. In some birds, the lingual secretions are used also in gluing together the ingredients used in building the nest such as swifts and swallows (Porter et al., 1996).

The present study was conducted to reveal the morphological, histological, as well as the histochemical aspects of the tongue of white-throated kingfisher $(H$. smyrnensis); a piscivorous bird and common buzzard (B. buteo); an omnivorous bird in an attempt to find out in more detail the correlation between the lingual anatomy and the nature of diets.

\section{MATERIAL AND METHODS}

\section{Experimental Animals:}

The experimental animals of the present work included two avian species feed on different diet. The investigated animals included white-throated kingfisher $(H$. smyrnensis) and common buzzard (B.buteo). White-throated kingfisher is exclusively piscevorous bird. The common buzzard on the other side is an omnivorous bird. White-throated kingfishers were collected from their natural environments; Nile delta. On the other hand, common buzzards were collected from Abo Rawash area in Giza governorate.

The two studied species were adult and healthy. Six adult males of each studied species were sacrificed with sharp razor blade. The heads of sacrificed animals were separated to remove out tongue from its root after separation of upper and lower jaw of the beak for subsequent investigations. For the purpose of this study, the tongues of four animals from each species were used for histological and histochemical 
investigation. On the other side the tongues of the other two animals were prepared for investigation by the scanning electron microscope.

\section{Scanning Electron Microscopic Studies:}

For the scanning electron microscope (SEM) investigation, the tongues of the selected species were rinsed with $0.1 \mathrm{M}$ phosphate buffer at $\mathrm{pH}$ 7.3. Postfixation was made in $1 \%$ sodium tetroxide solution for two hours at $4^{\circ} \mathrm{C}$. After dehydration through a graded ethanol series and infiltration by hexamethyl disilazin, the dried specimens were mounted on aluminum stubs and coated about $20 \mathrm{~s}$ gold-palladinum. The specimen was investigated at various angles under a scanning electron microscope (JSM-5300) at an accelerating voltage of $15 \mathrm{kV}$ in EM unit of the faculty of science, Ain Shams University.

\section{Histological and Histochemical Studies:}

The freshly removed tongues were washed under running tape water to remove any food debris and immediately fixed in $10 \%$ neutral formalin. The tissue was washed in tap water then dehydrated in ascending series of ethyl alcohols, cleaned in xylene and finally embedded in paraffin wax at $60^{\circ} \mathrm{C}$. The longitudinal and transverse paraffin sections at 5-6 $\mu \mathrm{m}$ in thick were prepared to represent the body and root of the tongue. Following de-paraffination and hydration, histological and histochemical staining techniques were undertaken using the sections. For routine histological investigation some of these sections were stained with Haematoxylin and Eosin according to Carleton (1980).

Other paraffin sections were used for the histochemical reactions listed below to determine the histochemical characteristics of the mucins found in the salivary glands (Bancroft \& Cook, 1984 and Kiernan 1989 ): (1) Periodic acid-Schiff (PAS) method for mucins (neutral mucosubstances) with vicinal glycol groupings (McManus, 1948); (2) Alcian blue (pH-2.5) - periodic acid-Schiff (AB-PAS) technique for acidic and neutral mucins (Mowry, 1956) and (3) Bromophenol blue method for detection of cellular protein (Mazia et al.,1953).

\section{RESULTS}

The tongue of the adult White-throated Kingfisher is characterized by a triangular format, its length is approximately $1.8 \mathrm{~cm}$ and occupies $1 / 2$ length of the beak. Three parts are distinguished on the dorsal surface of the tongue: the apex, the body and the root (Fig.1, a). On the other side, the tongue length of common buzzard is approximately $2 \mathrm{~cm}$ and occupies $2 / 3$ length of the beak, it has the same parts as those found in $H$. smyrnensis but is somewhat elongated and biforked at its apex. Moreover, the dorsal surface of the lingual body of common buzzard showed median groove (Fig. 1, b).

The scanning electron microscopic study revealed that the dorsal and ventral surfaces of the tongue of $H$. smyrnensis are completely covered with stratified squamous non- keratinized epithelium. The dorsal surface of the tongue apex is devoid of any processes, however, the posterior part of the tongue body and the root is covered with numerous fine processes among them, there are numerous and small orifices of mucus glands (Fig. 2 a). On the other side, the dorsal surface of the B.buteo tongue is covered with stratified squamous keratinized epithelium and the ventral surface is covered with thin stratified squamous non-keratinized epithelium. Moreover, the dorsal surface of the common buzzard tongue showed desquamated epithelial cells while, the lingual processes are completely absent (Fig. 2 b). 
The histological investigation of the tongue of the two studied species showed the same pattern of histological layers: outer epithelial layer, middle lamina propria and submucosa and inner muscular layer (Fig. 3 a \& b). The epithelial layer of the $H$. smyrnensis tongue is supplied by numerous connective tissue papillae carried capillary loops. In contrast, these vascular papillae are fewer in the lingual epithelium of common buzzard (Fig. $3 \mathrm{a} \& \mathrm{~b}$ ). The tongue apex of $H$. smyrnensis showed numerous simple tubular glands arranged in one row underneath the epithelial layer however, these glands are approximately absent in the tongue apex of $B$. buteo. The lamina propria of the tongue apex of $H$. smyrnensis is rich with connective tissue but devoid of lingual salivary glands. In contrast, the lamina propria of the tongue apex of B.buteo is characterized by presence of numerous simple branched tubular salivary glands and few connective tissues (Fig. $4 \mathrm{a \& b}$ ). The lingual body and root of $H$. smyrnensis showed high density of simple tubular mucus glands and numerous fine processes. Moreover, the lingual epithelium between the body and root is formed of psudostratified ciliated columnar cells (Figs. 3 a, \& Fig. 5 a, b). On the other side, the lingual body and root of B.buteo is devoid of simple tubular glands (Figs. $3 \mathrm{~b}$, \& Fig. $5 \mathrm{c}$,). The lamina propria of the lingual body and root of the B.buteo showed enlarged and widely distributed salivary glands than that of $H$. smyrnensis (Figs. 3 \& 5). The histological investigations also showed that the lingual muscle layer of $H$. smyrnensis is more developed than that of B.buteo and represents by longitudinal and transverse muscle bundles (Figs. 3-5).

The histochemical investigations of the lingual salivary glands of the two studied species showed significant variations in the degree of reactivity for the acid and neutral mucins as well as the cellular protein content (Table 1). The cells of the lingual salivary glands exhibited positive PAS reaction for the two studied species, in $H$. smyrnensis; this reaction was stronger than that of common buzzard (Fig. 6). After alcian blue PAS stain, the lingual salivary gland cells reacted positively with both stains, however the combined reaction for acid and neutral mucin in $H$. smyrnensis was stronger than that of B.buteo (Fig. 7). The bromophenol stain exhibited positive reaction in the cells of lingual salivary glands for the two studied species, where, the cells of the lingual salivary glands of B.buteo showed stronger protein reaction than that of H. smyrnensis (Fig. 8).

Table 1: The degree of reaction of lingual salivary glands for histochemical stains

\begin{tabular}{|l|c|c|}
\hline Stain & H. smyrnensis & B.buteo \\
\hline PAS & +++ & ++ \\
\hline AB(ph 2.5)- PAS & +++ & ++ \\
\hline Bromophenol blue & + & +++ \\
\hline \multicolumn{2}{|l|}{+ Weak reaction $\quad++=$ Moderate reaction $\quad+++=$ Strong reaction }
\end{tabular}

\section{DISCUSSION}

The structure of the tongue of birds frequently gives some clue to the principal diet and manner of feeding in each species, for example probe or spear in woodpeckers, sieve in ducks, capillary tube in sunbirds, brush in Trichglossidae, rasp in vulture and barbet in penguin (Poost et al.,2010 ; El-Bakary, 2011). The shape of the tongue in birds is a species specific trait and closely fits the shape of the lower part of the bill (Campbell \& Lack 1985; Vollmerhaus \& Sinowatz, 1992; Parchami et al., 2010). The tongue in many species of birds is a triangular organ that fills the whole lower part of the bill (McLelland, 1990; Grant \& Temeles, 1992). Strongly elongated tubular tongues can be found in hummingbirds, sunny birds and woodpeckers 
(Harrison, 1964; Campbell \& Lack, 1985). Elongated flat tongues can be found in waterfowl, such as geese and ducks (Iwasaki \& Kobayashi, 1986; Iwasaki et al., 1997). The tongues of some fish eating birds such as pelicans and cormorants undergo a distinct structural reduction (Campbell \& Lack, 1985). The tongue of the cormorant is a small mushroom-shaped connective tissue (Jackowiak et al., 2006).

Results obtained from the present study showed that the tongue of $H$. smyrnensis and B.buteo like many other birds have a triangular and elongated format respectively, and both of them fill the whole lower part of the bill. Moreover, the present results also showed that in common buzzard, the tongue apex is biforked and the body has a median dorsal groove dividing the tongue into two symmetrical halves. Such observations go parallel with the findings of McLelland (1975) on some domestic birds; Jackowiak and Godynicki, (2005) on white tailed eagle. In contrast, the forked and grooved tongue is absent in penguin (Kobayashi et al., 1998) and in chickens (Iwasaki and Kobayashi, 1986). From the anatomical point of view, the forked and grooved tongue of B.buteo may play a major role in free movement of the tongue and subsequently easy capture of the fine parts of foods.

In the present work, the scanning electron microscopic study revealed that the dorsal surface of tongue body and root of $H$. smyrnensis is covered with numerous sharp, fine processes however, these processes were completely absent in B.buteo. Such results are in accordance with the findings of Iwasaki (1992) and Kobayashi et al. (1998) who reported that, the hard fine processes of the tongue are useful for holding and keeping food on the tongue, such as fish, within the mouth. Also they added that, these structures act co-operatively during feeding and mastication. On the other side, the dorsal lingual surface of B.buteo is covered with thick stratified squmamous keratinized epithelium however this keratinization was absent in the tongue of $H$. smyrnensis. Similar results were observed in different species of birds. However, the keratinized layer of the epithelium usually differs in thickness depending on the type of food. A strongly keratinized epithelium is seen mainly in herbivorous and granivorous birds (Susi, 1969; Iwasaki, 1992; Jackowiak \& Godynicki, 2005; Jackowiak \& Ludwing, 2008). A lesser degree of keratinization of the epithelium is found in birds living in water habitats (Iwasaki, 2002; Jackowiak et al., 2006; Kadhim et al., 2011).

In the present work, the histological investigations showed that, the dorsal lingual epithelium of the H.smyrnensis is supplied with numerous connective tissue papillae that contain capillary loops, however this vasculariztion was absent in the lingual epithelium of hawk. Such findings are in contrast with the results of Feder (1972) on greater rhea; Tivane (2008) and Crole \& Soley (2009) on Ostrich. They mentioned that, in omnivorous birds the lingual connective tissue paplillae are needed to facilitate moisture of the tongue surface. The presence of connective tissue papillae in the lingual epithelium of H.smyrnensis in spite of it is a piscivorous bird may play a role in moistening of tongue to decrease the friction with water during the capture of fish. On the other hand, the absence of lingual connective tissue papillae in common buzzard may be related to the nature of diet which are mostly soft foods and rarely dry grains and consequently not need for moistening of tongue surface. The light microscopic investigation of the present work also showed that, in H.smyrnensis, the lingual body and root are covered with numerous fine processes however; these processes were absent in the tongue of common buzzard. Emura et al. (2008) and Kadhim et al. (2011) have demonstrated the importance of the lingual processes which includes assisting the transfer of food towards the esophagus as well as prevent regurgitation. In particular, the junction between the lingual body and root of white- 
throated kingfisher showed that, the lingual epithelium is formed of pseudostratified ciliated columnar epithelium. From the histological point of view, this epithelium may play a key role in protecting the tongue; secrete mucus by goblet cells, and mixing of mucus to the food by cilia.

In addition, the histological results revealed that in $H$. smyrnensis there are two types of lingual salivary glands; simple tubular mucus glands and simple branched tubular glands. The first type is arranged as one row in the lingual epithelium (superficial type) along the whole length of the dorsal epithelium while the second type is more localized in the lamina propria (deep type) of tongue body and root. On the other side, B.buteo tongue showed only simple branched tubular glands which are distributed in the lamina propria of the tongue and more branched and developed than that of $H$. smyrnensis. These finding are consistent with the results of Farner and Ziswiller (1972), McLelland (1979), King and McLelland, (1984) and Blanks (1993) who recorded that, the structure of lingual salivary glands is more developed and complex in birds that feed on dry food like seeds as compared to those having access to naturally well moist food as fishes. For more specification focused on $H$. smyrnensis, this finding is in contrast with the results of Samar et al. (1995) who disagree with the results of Farner and Ziswiller (1972) who found that the salivary glands of fish-eating birds are poorly developed. The presence of lingual simple tubular glands in $H$. smyrnensis rather than $B$. buteo may be considered as a continuous source for mucus secretion that involved in nest building.

The discrepancy between the results might be due to genetic variations in the different avian species. However, more work is needed for explanation.

The recorded histochemical investigations on the lingual salivary glands of the two studied species revealed that both of them are positively reacted to PAS stain, alcian blue-PAS and for bromophenol with variable degree of reaction intensity. In $H$. smyrnensis, the salivary glands showed stronger reaction for both of PAS and alcian blue- PAS stains in comparing with those in B. buteo and hence the cells of the lingual salivary glands of $H$. smyrnensis considered being rich with neutral mucosubstances and acid mucosubstance than that of common buzzard. The data concerning stronger reaction for neutral mucosubstances in lingual salivary glands of $H$. smyrnensis are disagree with that of Al-Mansour and Jarrer (2007) on the piscevorous little egret who demonstrated that the lingual salivary glands of Egretta garzetta are devoid of glycogen or neutral mucosubstances. On the other side, the present results agree with the same authors for the existence of strong reaction for acid mucosubstances. The moderate reaction for the neutral and acid mucosbtances in the lingual salivary glands of $B$. buteo go parallel with the results of AI-Mansour and Jarrar (2004) on White- Cheeked Bulbul, Kadhim et al.(2011) on Gallus gallus and Erdogan et al. (2012) on Chukar partridge. Moreover, the current results showed stronger reaction for protein stained with bromophenol technique in the lingual salivary glands of B.buteo in compared with weak reaction of $H$. smyrnensis. The result concerning intense protein reaction in B.buteo tongue is in accordance with the findings of Taib and Jarrar (1998) on coturnix and Taib and Jarrar (2001) on Streptopelia decaocta. In contrast, the recorded weak protein reaction in the lingual salivary glands of $H$. smyrnensis is inconsistent with the results of Al-Mansour and Jarrar (2007) who detect strong protein reaction in the tongue of piscivorous Egretta garzetta. In the present search, the secretory products of the lingual salivary glands of the two studied avian species form a blend of mucoserous secretions that contain mucosubstances and proteins but with predominant mucous secretions for $H$. smyrnensis tongue and predominant proteins secretion for B.buteo tongue. The lingual 
salivary glands form a blend of mucinous saliva that may act as lubricate to manipulate the ingested food to facilitate swallowing. Moreover, secretions of the mucous lingual glands may act as a protective cover to the mucous membrane of the upper digestive tract whose activity is similar to those suggested by Samara et al. (2002) and Kadhim et al. (2011).

More investigations are needed to find whether the structure and the secretions of the lingual salivary glands are related to the phylogeny and/or the changes in the feeding habits or not?

\section{REFERENCES}

AI-Mansour, M.I. and Jarrar,B.M. (2007). Morphological, Histological and Histochemical Study of the Lingual Salivary Glands of the Little Egret, Egretta garzetta . Saudi.J.Biol.Sci., 14 (1): 75-81.

AI-Mansour,M.I. and Jarrar, B.M. (2004). Structure and Secretions of the Lingual Salivary Glands of the White- Cheeked Bulbu, Pycnonotus leucogenys (Pycnontidae).Saudi.J.Biol.Sci., 11(2):119-126.

Bancroft, J.D. and Cook, H.C. (1984). Manual of Histological Techniques (Edinburgh, London, Melbourne, and New York, Churchill Livingstone).

Blanks, W.J. (1993). Applied Veterinary Histology. St. Louis: Mosby Year Book, 356 pp.

Campbell, B. and Lack, E. (1985). A Dictionary of Birds Calton T. \& AD. Poyser.

Carleton, T. (1980). Carleton`s Histological Technique, 5th edn. Revised and Rewritten by: R. A. B. Drury and E. A. Wallington.

Carver, W.E. and Sawyer, R.H. (1989). Immunocytochemical localization and biochemical analysis of $\alpha$ and $\beta$ keratins in the avian lingual epithelium. Am. J. Anat., 184: 66-75.

Crole, M.R. and Soley, J. T. (2009). Morphology of the tongue of the emu (Dromaius novaehollandiae). II. Histological features. Onderstepoort J. Vet. Res., 76: 347-361

El-Bakary, N. E.R. (2011). Surface Morphology of the Tongue of the Hoopoe (Upupa Epops) J. Am. Sci., 7(1): 394-399

Emura, S. and Chen H. (2008). Scanning electron microscopic study of the tongue in the owl (Strix uralensis). Anat. Histol. Embryol., 37: 475-478

Emura, S.; Okumura, T. and Chen, H. (2008). Scanning electron microscopic study of the tongue in the peregrine falcon and common kestrel. Okajimas Folia Anat. Jpn., 85(1): 11-15.

Erdogan,S.; Sagsoz, H. and Akbalik, M.E. (2012).Anatomical and histological structure of the tongue and histochemical characteristics of the lingual salivary glands in the Chukar partridge (Alectoris chukar, Gray 1830).British Poultry Sci., 53 ( 3) :307-315

Farner, D. and Ziswiller, V. (1972). Digestion and digestive system. In: Avian biology. Volume 3, Farner,D.S. and King, J.R. (Eds.) London: Academic Press, pp.343-430.

Feder, F.H. (1972). Zur mikroskopischen Anatomie des Verdauungsapparates beim Nandu (Rhea americana). Anatomischer Anzeiger, 132:250-265.

Fujii, T. and Tamura, S. (1966):Histochemical studies on the mucins of the chicken salivary glands. J.Fac. Fish. Anim. Husb., Hiroshima Univ., 6: 345-55.

Ganchrow, D. and Ganchrow, J.R. (1985). Number and distribution of taste buds in the oral cavity of hatching chicks. Physiol.Behav. 34, 889-894. 
Gentle, M.J. (1971). The lingual taste buds of Gallus domesticusL. Br. Poultry Sci., $12: 245-248$.

Grant, V. and Temeles, E.J. (1992). Foraging ability of rufous hummingbirds on hummingbird flowers and hawk moth flowers. Proc. Natl. Acad. Sci. USA., papillae 89: 9400-9404.

Harrison, J.G. (1964). Tongue. In A New Dictionary o f Birds Ed by A Thompson, Nelson, London.

Homberger, D.G. and Brush, A. (1986). Functional-morphological and biochemical correlations of the keratinized structures in the African grey parrot, Psittacus erithacus (Aves). Zoomorphology 106:103-114.

Homberger, D.G. and Meyers, R. (1989). Morphology of the lingual apparatus of the domestic chicken Gallus gallus, with special attention to the structure of the fasciae. Amer J .Anat., 186: 217-257

Iwasaki, S. (1992). Fine structure of the dorsal lingual epithelium of the little tern, Sterna albifrons Pallas (Aves, Lari). J.Morph., 212:13-26.

Iwasaki, S. Kobayashi, K. (1986). Scanning and transmission electron microscopical studies on the lingual dorsal epithelium of chickens. Acta Anat Nippon, 61: 83-96

Iwasaki, S.; Asami, T. and Chiba, A. (1997). Ultrastructural study of the keratinization of the dorsal epithelium of the tongue of Middendorff's bean goose, Anser fabalis middendorffii (Anseres, Anatidae). Anat. Rec., 247: 149-163.

Iwasaki, S.T. (2002). Evolution of the structure and function of the vertebrate tongue. J. Anat. 201: 1-13.

Jackowiak, H. and Ludwing, M.(2008). Light and scanning electron microscopic study of the structure of the Ostrich (Strutio camelus) tongue. Zool. Sci., 25: 188-194.

Jackowiak, H.and Godynicki, S. (2005). Light and scanning electron microscopic study of the tongue in the white tailed eagle (Haliaeetus albicilla, Accipitriadae, Aves). Ann. Anat., 187: 251- 259

Jackowiak,H.; Andrzejewski, W.and Godynicki, S. (2006). Light and scanning electron microscopic study of the tongue in the Cormorant Phalacrocorax carbo (Phalacrocoracidae, Aves). Zool. Sci., 23: 161-167

Jerrett, S.A. and Goodge, W.R. (1973). Evidence of amylase avian salivary glands. J. Morph., 139:27-46.

Kadhim, K.K.; Zuki, A.B.Z.; Babjee , S.M.A.; Noordin, M.M. and Zamri-Saad, M.(2011). Morphological and histochemical observations of the red jungle fowl tongue Gallus gallus, African J. Biotec., 10(48):9969-9977.

Kiernan, J. H. (1989). Methods for connective tissues. In: Histological and histochemical methods. Theory and practice. 2nd. Ed., Pergamon press, Oxford, pp. $115-131$.

King, A.S. and Mclelland, J. (1984). Birds: Their Structure and Function. London : Bailliere, 88-89 pp.

Kobayashi, K.; Kumakura, M.; Yoshimura K.; Inatomi, M.and Asami, T.(1998). Fine structure of the tongue and lingual papillae of the penguin. Arch. Histol. Cytol., 61: $37-46$.

Kutuzov, H. and Sicher, H. (1951). The filiform and the conical papillae of the tongue in the white rat. Anat. Rec., 110:275-288.

Mazia, D.; Brewer, P.A. and Alfert, M. (1953). The cytochemical staining and measurement with mercuric bromophenol blue. Biological Bulletin, 104: 57-67. 
MC Manus, J.F.A. (1948). Histological and histochemical uses of periodic acid. Stain Technology, 23: 99-108.

McClelland, J. (1975). Aves digestive system. In: R Getty (Ed.). Sisson and Grossman's the Anatomy of the Domestic Animals. Saunders Company, Philadelphia, London, Toronto.

McLeland, L. (1979). Digestive system. In: Form and function in birds. King, A.S. and McLelland, L.M. (Eds). London: Academic Press, pp. 170-181

McLelland, J. (1990). A Color Atlas of Avian Anatomy. Wolfe Publishing Ltd.

Mowry , R.W. (1956). Alcian blue techniques for the histochemical study of acidic carbohydrates. Journal of Histochemistry and Cytochemistry, 4: 407-408.

Parchami,A.; Fatahian Dehkordi, R.A. and Bahadoran ,S.(2010). Fine Structure of the Dorsal Lingual Epithelium of the Common Quail (Coturnix coturnix), World Applied Sciences Journal., 10(10): 1185-1189

Poost, P.A.;Tadjalli, M. and Mansouri, H. (2010). Microscopic Study on the Tongue of Male Ostrich, Eur. J. Biol. Sci., 2 (2): 24-31

Porter, R.E; Christensen, S. and Schiermacker-Hansen, P. (1996). Field guide to the birds of the Middle East. T \& AD Poyser Ltd., London.

Rossi, J.R.; Baraldi-Artoni, S.M.; Oliveria ,D.; Cruz, C.;Franzo V.S.and Sagula, A. (2005). Morphology of beak and tongue of partridge Rhynchotusrufescens. Cienca Rural 35: 1098-1102

Samar, M.E.; Avila ,R.E.; Esteban, F.J.; Olmedo, L.; Dettin, L.;Massone, A.;Pedrosa, J.A.and Peinnado, M.A.(2002). Histochemical and ultrastructural study of the chicken salivary palatine glands. Acta Histochem., 104:199-207.

Samar, M.E.; Avila, R.E.; De Fabro, S.P. and Centurion, C. (1995). Structural and cytochemical study of salivary glands in the magellanic penguin Spheniscus magellanicus and the kelp gull Larus dominicanus. Marine Ornithology, 23: 154-156.

Susi, F.R. (1969). Keratinization in the mucosa of the ventral surface of the chicken tongue. J. Anat., 105: 477-486.

Taib, N.T. and Jarrar, B.M.(1998). Histological and histochemical characterization of the lingual salivary glands of the quil, Coturnix coturnix.Saudi J.Bio. Sci., 5 (2):33-41.

Taib, N.T. and Jarrar, B.M. (2001). Histochemical characterization of the lingual salivary glands of the Eurasian collared dove, Streptopelia decaocia.Pakistan J. Bio. Sc., 4 (11):1425-1428

Tivane, C. (2008)j A morphological study of the oropharynx and oesophagus of the ostrich (Struthio camelus). M.Sc. dissertation, University of Pretoria.

Vollmerhaus, B. and Sinowatz, F. (1992).Verdauungsapparat. In: Nickel, R., Schummer E., Seiferle E. (Eds.). Anatomie der Vögel Bd. 5. Lehrbuc der Anatomie der Haustiere, Parey, Berlin. 

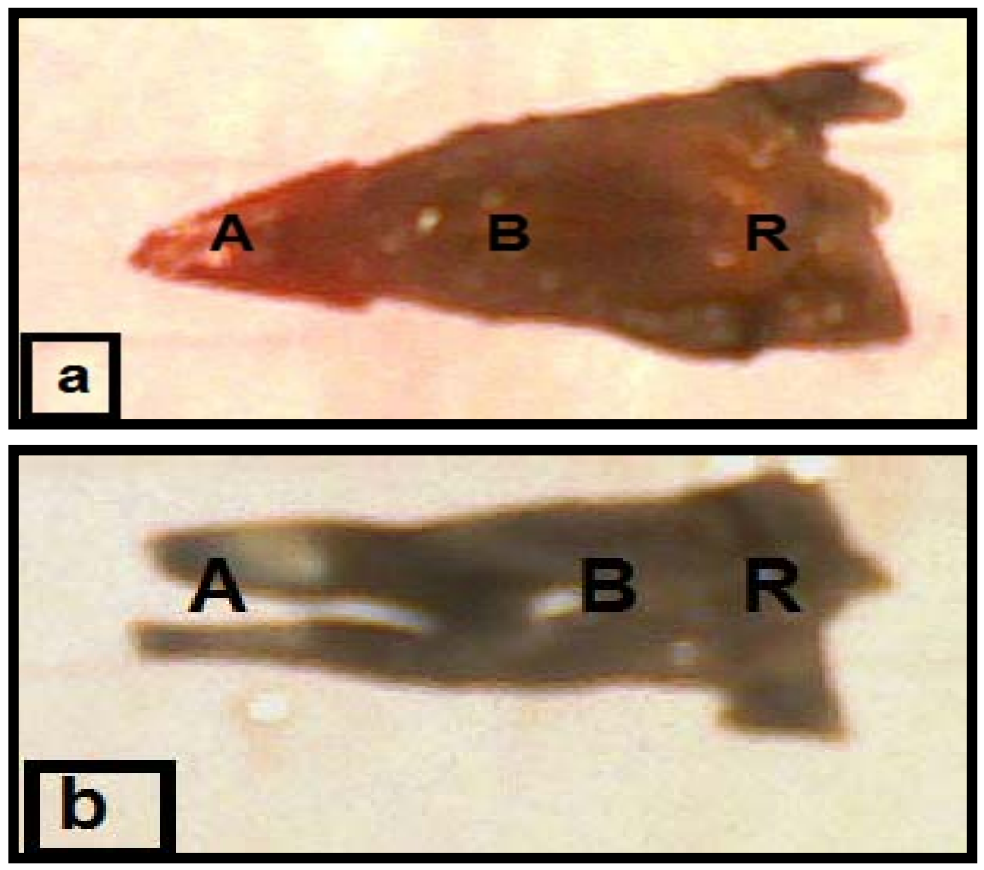

Fig.1: Photographs of the tongues of H.smyrnensis (a) and B. buteo (b) showing the main morphological parts of the tongue; the apex (A), the body (B) and the root (R) Note:The biforked tongue apex of $B$. buteo.
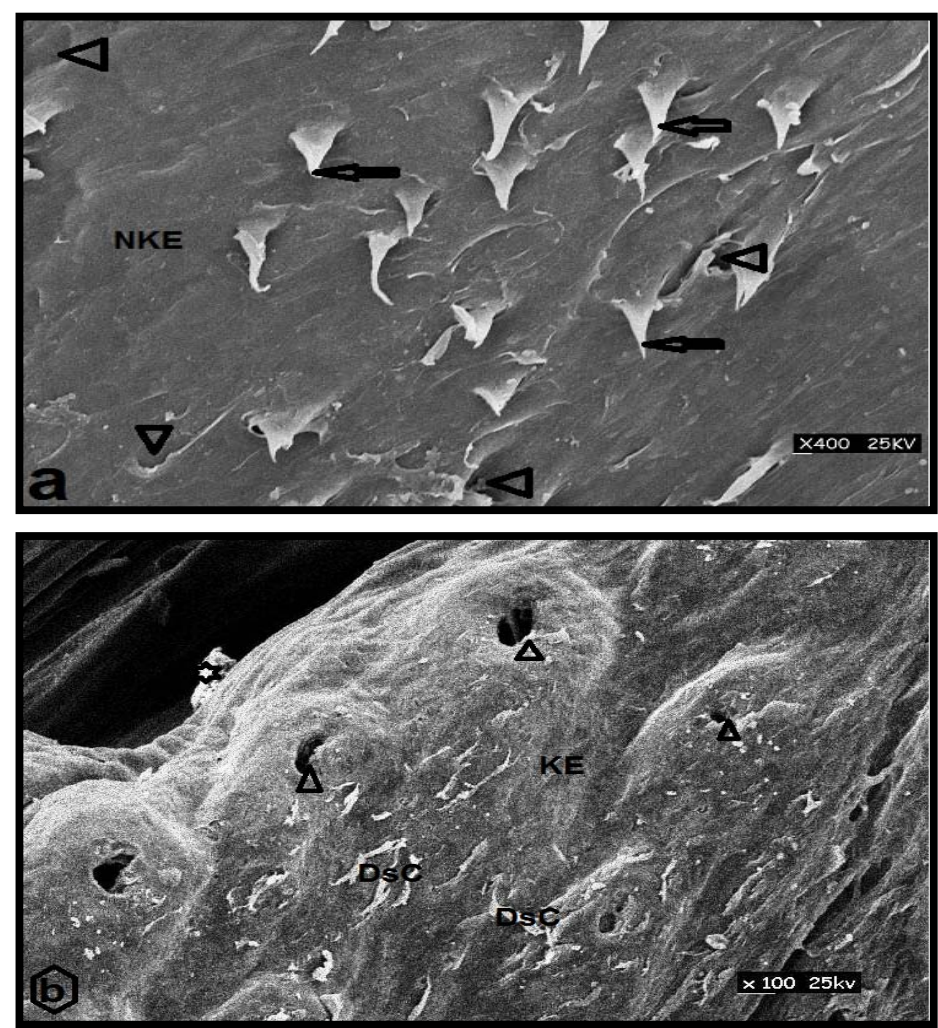

Fig. 2: Scanning electron micrograph of the dorsal surface of the tongue of $\boldsymbol{H}$. smyrnensis (a) and $B$. buteo (b) showing nonkeratinized epithelium (NKE), Keratinized epithelium (KE), Desquamated cells (DsC), fine processes (arrows), glandular orifices (arrowheads), collections of salivary secretions (star). 

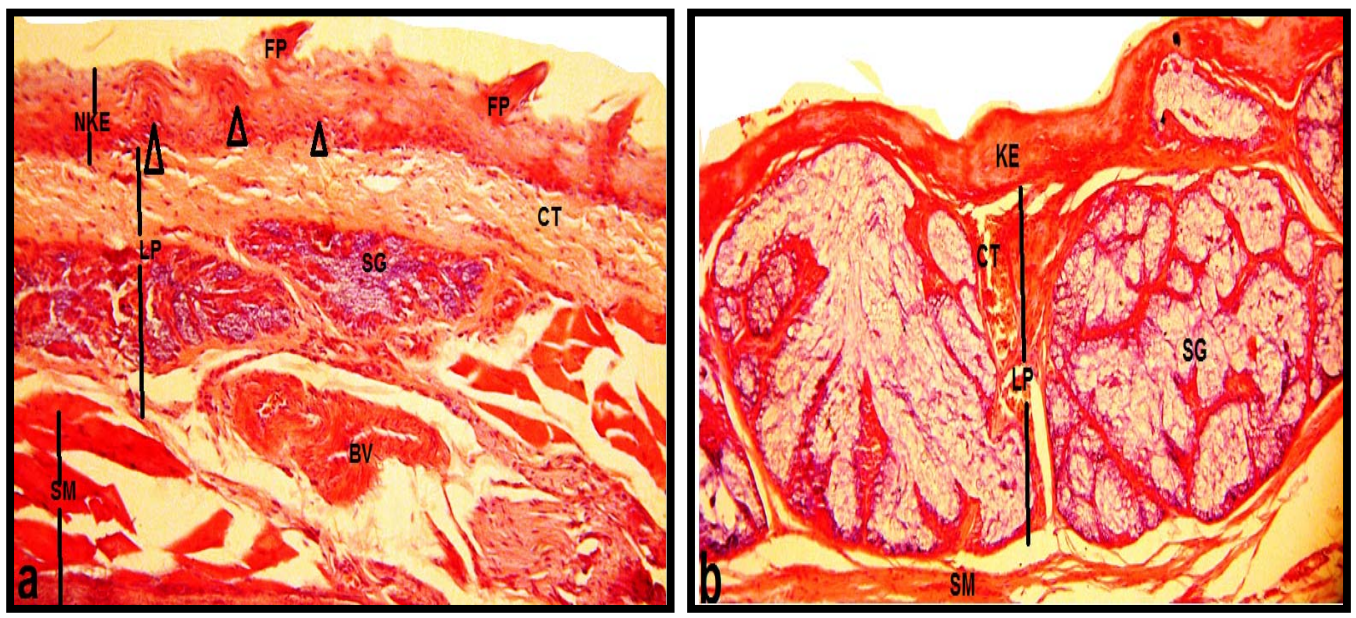

Fig. 3: Photomicrographs of longitudinal histological sections in the tongue body of $\boldsymbol{H}$. Smyrnensis (a) B.buteo (b) showing nonkeratinized epithelium (NK), fine processes (FP), Keratinized epithelium (KE), Lamina propria (LP), Slivary glands (SG), Connective tissue (CT), Cnnective tissue (CT), Connective tissue papillae (arrow heads), blood vessels (BV), Skeletal muscles (SM). H. \&E. X: 400
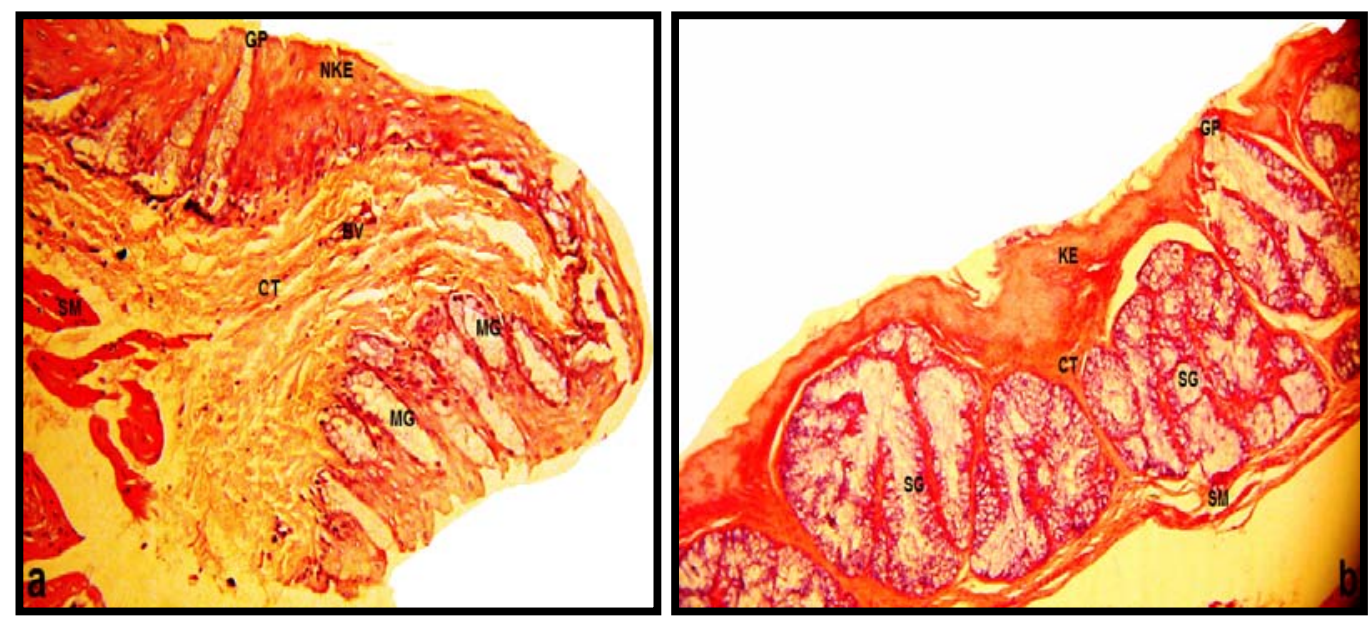

Fig. 4: Photomicrgraphs of longitudinal histological sections in the tongue apex of $\boldsymbol{H}$. smyrnensis (a) and B. buteo (b) showing nonkeratinized epithelium (NKE),simple mucus glands (MG) with glandular pore(GP), Keratinized epithelium (KE), simple branched tubular Slivary glands (SG),Smooth muscles(SM). H. \&E. X.250 

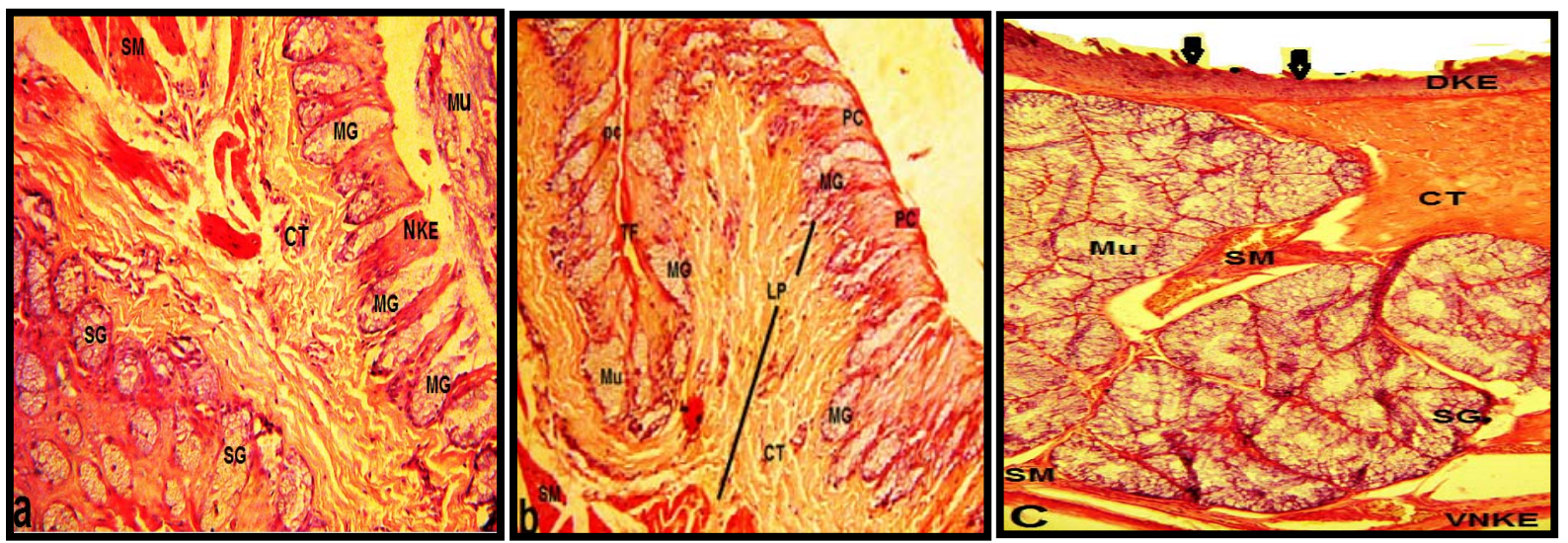

Fig. 5: Photomicrgraphs of longitudinal histological sections in the tongue root of $\boldsymbol{H}$. smyrnensis $(\mathbf{a}, \mathbf{b})$ and B.buteo (c) showing nonkeratinized epithelium (NKE),simple mucus glands (MG), pseudostratified ciliated columnar epithelium (PC), Dorsal Keratinized epithelium (DKE), Ventral non-keratinized epithelium (VNKE), simple branched tubular Slivary glands (SG), mucins (Mu), Skeletal muscles (SM), desquamated cells (arrows

Note, the pseudostratified ciliated columnar epithlium is existed at the junction between the lingual body and root of $\boldsymbol{H}$. smyrnensis. The tongue root of $\boldsymbol{B}$. buteo is devoid of simple mucus glands. H. \&E. X: 250.
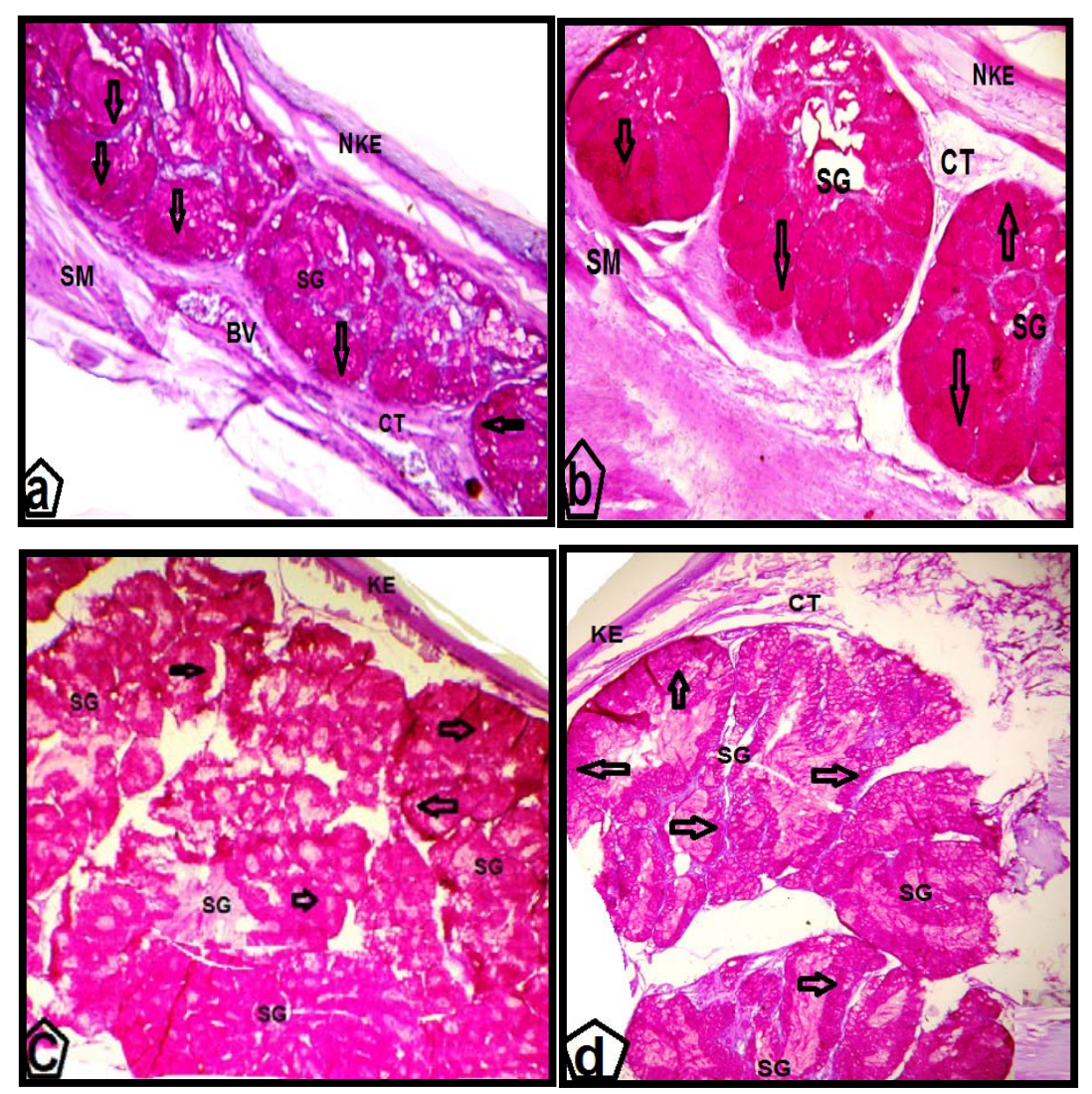

Fig. 6: Photomicrgraphs of histological sections through the lingual salivary glands of $\boldsymbol{H}$. smyrnensis $(a, b)$ and $B$. buteo $(c, d)$ stained with PAS.

Note: The lingual salivary glands of $\boldsymbol{H}$. smyrnensis showing stronger reaction for neutral mucins in comparing with those of $\boldsymbol{B}$. buteo (the arrows refere to the inensity of PAS reaction), nonkeratinized epithelium (NKE), Keratinized epithelium (KE), simple branched tubular Slivary glands (SG), mucins (Mu), Skeletal muscles (SM),Coonnective tissue (CT) blood vessels (BV). $(\mathrm{a}, \mathrm{c}) \mathrm{X}: 250(\mathrm{~b}, \mathrm{~d}) \mathrm{X} .400$. 


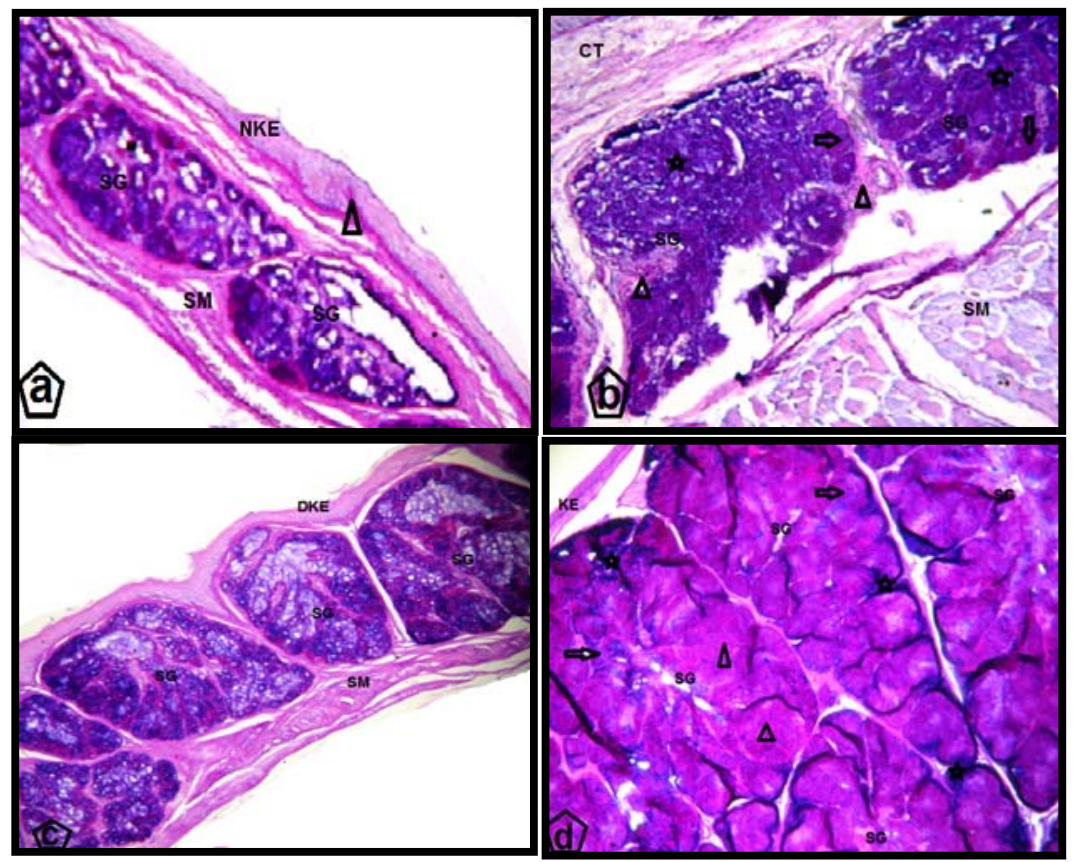

Fig. 7: Photomicrgraphs of transverse histological sections through the lingual salivary glands of $\boldsymbol{H}$. smyrnensis (a-b) and B. buteo (c-d) stained with Alcian blue- PAS

Note: The lingual salivary glands of $\boldsymbol{H}$. smyrnensis showing stronger reaction for both neutral and acid mucins in comparing with those of $\boldsymbol{B}$. buteo, AB reaction (arrows), PAS reaction (arrowheads), mixed reaction (stars), nonkeratinized epithelium (NKE )Dorsal Keratinized epithelium (DKE), simple branched tubular slivary glands (SG), Skeletal muscles (SM), Coonnectivetissue (CT), Blood vessels (BV) $(\mathrm{a}, \mathrm{c}) \mathrm{X}: 250(\mathrm{~b}, \mathrm{~d}) \mathrm{X}: 400$

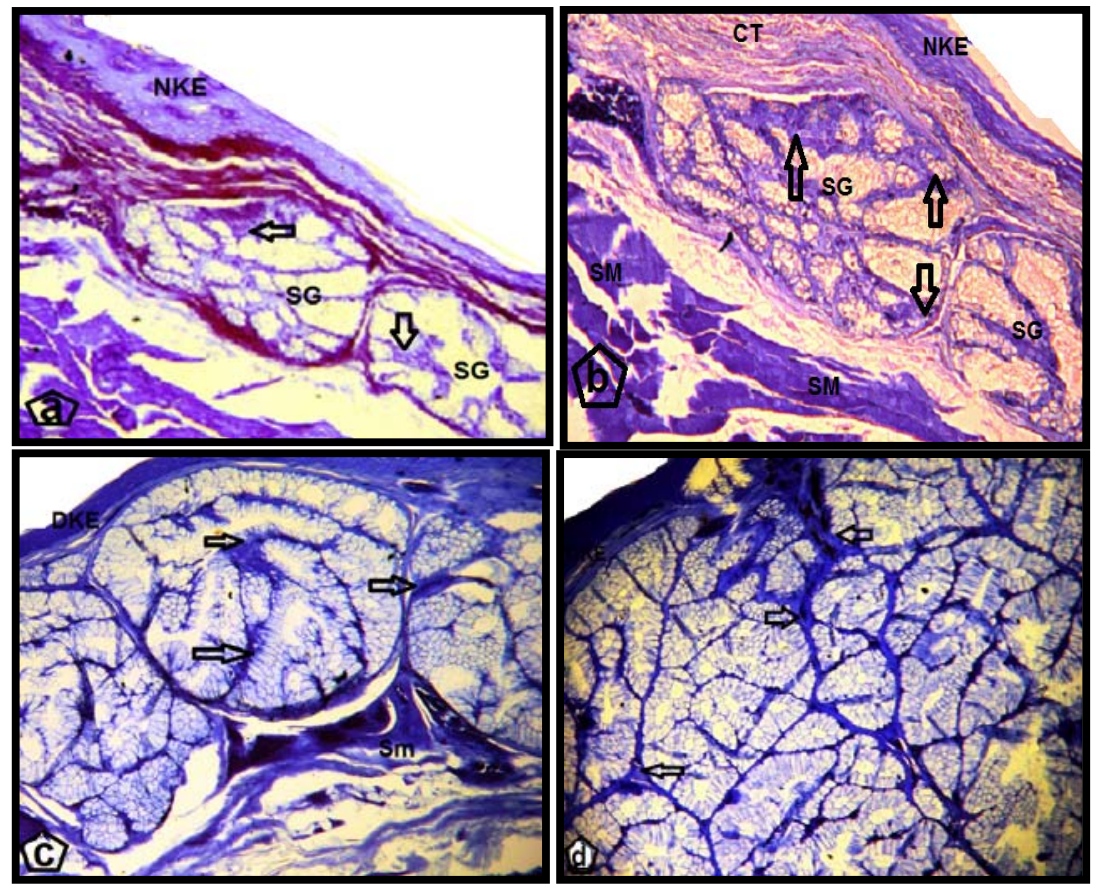

Fig. 8: Photomicrographs of transverse histological sections through the lingual salivary glands of $\boldsymbol{H}$. smyrnensis (a-b) and $\boldsymbol{B}$. buteo (c-d) stained with bromophenol-blue.

Note: The lingual salivary glands of $\boldsymbol{B}$. buteo showing stronger protein reaction in comparing with those of $\boldsymbol{H}$. smyrnensis. The arrows refer to the intensity of protein reaction, Nonkeratinized epithelium (NKE), Dorsal Keratinized epithelium (DKE), simple branched tubular Slivary glands (SG), Skeletal muscles (SM). (a,c) X: 250, (b,d) X: 400 


\section{ARABIC SUMMERY}

\section{دراسات مقارنة على اللسان فى صياد السمك ذو الرقبة البيضاء وصقر كوهية}

$$
\begin{aligned}
& \text { عبد الفتاح البلتاجى محمد } \\
& \text { قسم علم الحيو ان- كلية العلوم- جامعة دمنهور }
\end{aligned}
$$

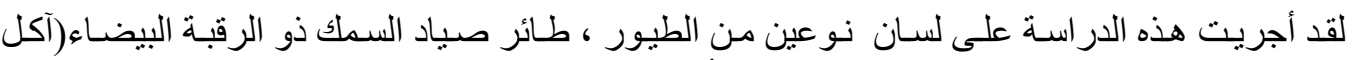

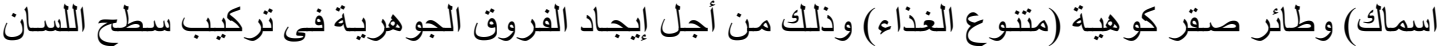

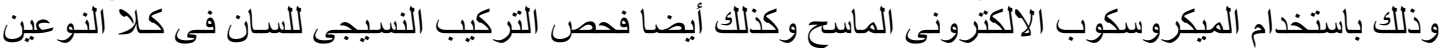

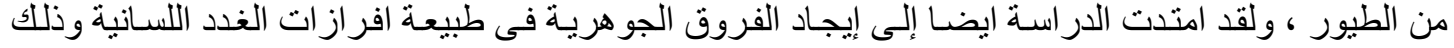
باستخدام الطرق الكيمونسيجية.

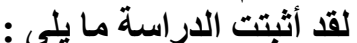
أن الثكل الظاهرى للسان فى كلا النوعين من الطيور ينقسم إلى 3 مناطق: مقدمة اللسـان وجسم اللسـان

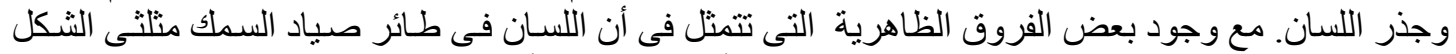

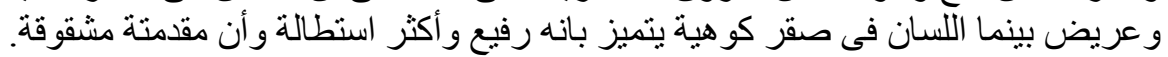

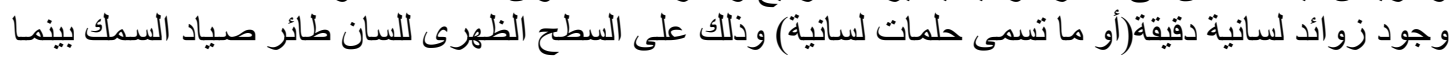

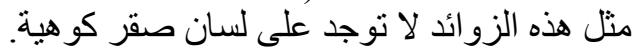
وجود طبقة كير اتينية على السطح الظهرى للسـان صقر كو هيـة بينمـا تلك الطبقة غير موجودة على لسـان طائر صياد السمك. فى كلا النو عين من الطيوريتميز نسيج اللسان الى 3 طبقات : طبقة طلائية خارجية ، وطبقة غدية وسطية وطبقة

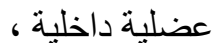
تتميز الطبقة الطلائية فى لسان صباد السمك بوجود العديد من الغدد المخاطية البسيطة وكذلك حلمات مدتدة من

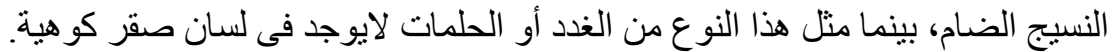

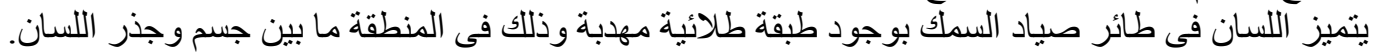

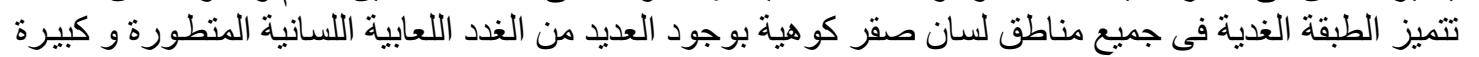

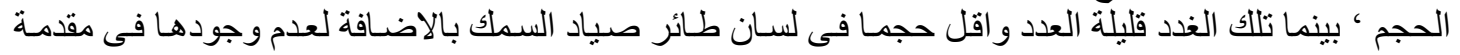
اللسان. - - إن الطبقة العضلية فى لسان طائر صبياد السمك اكثر سمكا وبها العديد من الالياف العضلية العرضية و الطولية. عن تلاك الموجودة فى لسان صقر كو هية.

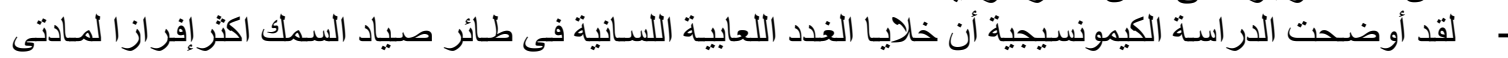

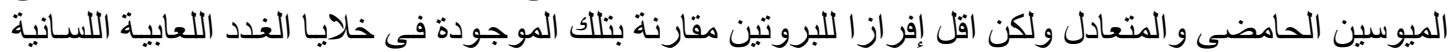
لصقر كو هية. 